\title{
The Influence of Elections on IMF Programme Interruptions
}

\author{
AXEL DREHER
}

Using panel data for 104 countries between 1975 and 1998, this article tries to explain interruptions of IMF programmes around election dates in the recipient countries. On average, programmes seem to be more likely to break down before elections. This increase in interruption probabilities is, however, less severe in more democratic countries. In true democracies interruption frequencies are even lower prior to elections. While no other political variables than elections and democracy were found to influence compliance systematically, programme interruptions are significantly more likely in countries with high government consumption, high levels of short-term debt and low GDP per capita at programme initiation.

\section{INTRODUCTION}

When the IMF was founded in Bretton Woods in 1944, there was no consideration of intrusive conditionality now common under its programmes. The Fund was assigned the task to provide short-term balance of payments credits and stabilise the post war financial system. However, over time, with the evolution of the IMF, conditionality gradually increased and became inseparably associated with its loans. Now, an average IMF programme includes about 20 conditions. Moreover, whereas conditions initially covered only a few areas of major importance for programme success, newer arrangements severely limit creditor government's leeway. ${ }^{1}$ Not all of these conditions have, however, been implemented as negotiated. Quite the contrary, non-compliance seems to be common.

Axel Dreher, University of Mannheim, Lehrstuhl für Volkswirtschaftslehre, L7, 3-5, D-68131 Mannheim, Germany; e-mail: mail@axel-dreher.de. The author is grateful for many helpful suggestions by Bernhard Boockmann, Roland Vaubel, the participants of the HWWA workshop on Public Choice and Development on 9 November 2001 and the Annual Meeting of the European Public Choice Society, 4-7 April 2002, especially Jakob de Haan and an anonymous referee of this journal. All errors are mine.

The Journal of Development Studies, Vol.39, No.6, August 2003, pp.101-120

PUBLISHED BY FRANK CASS, LONDON 
Programme interruptions may occur for different reasons. First, exogenous shocks might prevent the government from implementing the agreed conditions. A worsening of the external macroeconomic situation could lead to deficits or inflation rates higher than targeted. While, as a consequence, disbursements are temporarily suspended, the failed targets will be waived if agreement on future conditions can be achieved. This is particularly likely if initial IMF conditions have been too demanding. But even if the environment improves programmes might be interrupted. Since creditor governments in this case no longer need the IMF, they might decide to postpone or quit unwarranted structural adjustment measures. Due to this non-compliance the IMF interrupts tranche disbursements. Second, loan conditions often contradict the recipient government's own agenda. Since failure to implement agreed conditions is not punished by the IMF, governments might nevertheless agree to those conditions, well knowing in advance that slippage will occur. After the release of one or two tranches non-compliance becomes obvious, so the IMF interrupts or cancels the arrangement.

There is now a widespread perception that programme ownership is most important to successful implementation of IMF policies [Johnson and Wasty, 1993] and that it is not possible to substitute for that ownership with conditionality [IMF, 2001; Stevens and Gnanaselvam, 1995]. For example, Dollar and Svensson [1998] showed, that governments which are inclined to reform must be identified and can not be created by international organisations. In order to design effective programmes, it would therefore be most important for the IMF to detect factors influencing ownership and thus the willingness to reform.

The will to comply with arrangements negotiated between a government and the IMF might be influenced by national politics. Especially, elections in programme countries could influence the authority's capacity to implement restrictive austerity measures. Schuknecht [1996] has shown that developing countries' governments try to improve their re-election prospects with expansionary fiscal policies. Dreher and Vaubel [2004] report evidence that monetary growth rates are also higher prior to elections. In the words of the IMF [1997], elections result in government overspending and a general distraction of policy-makers. As a consequence of the resulting non-compliance with programme conditions, the Fund might cancel the arrangement [Mecagni, 1999: 223]. Moreover, since IMF programmes are often highly contentious, sticking to them - even without implementing restrictive measures - could reduce the incumbent's chance for re-election. In some cases the government might therefore decide to openly reject the previously agreed upon conditionality. This should lead to more interruptions in the eve of elections. 
On the other hand, Fund programmes might be even less likely to break down prior to elections. There are two possibilities. First, even if noncompliance is evident the IMF may not want to damage a government's reputation in the run-up of elections. Since the Fund could be blamed for the defeat of the incumbent, it may grant a waiver and pay out another tranche before interrupting the programme after the election. The IMF may also believe that non-compliance is only temporary and will be reversed after the elections. Thus, it may decide not to cancel the arrangement. Second, the breakdown of an arrangement could be interpreted by the voters as failure of the incumbent. A government that has already borne the sometimes high political costs of negotiating an arrangement might want to maintain the programme in the eve of an election. Thus, governments are probably inclined to agree to harsh future conditionality to prevent the arrangement from breaking down.

Evidence about the effects of elections on credit provided by the IMF was provided by Dreher and Vaubel [2004]. They showed that, on average, new net credit from the IMF is significantly larger in pre- and post-election years. The larger amount of net credit drawn prior to elections does, however, not necessarily mean that less programmes are cancelled in these years. An alternative explanation might be that repayments are postponed or more programmes are negotiated at election times. The observation of higher postelection year credit leads to a second part of the hypothesis: Since Fund conditionality can be used to justify restrictive macroeconomic policies after the election, fewer programmes should be cancelled during those years. If, however, a new government is elected, it may decide not to comply with the conditions negotiated between its predecessor and the IMF. Moreover, if the incumbent is re-elected, he may decide not to comply with the conditions agreed prior to the election because - after the election - the perceived tradeoff between the cheap money and reduced political leeway may have changed. As a consequence, the IMF, having been quite lenient during the election year, may eventually cancel the programme. Thus, it is not clear a priori whether interruptions are more or less likely around elections.

The question addressed here has some similarity to the question of the duration of IMF programmes. Joyce [2001] reported that programme duration is higher for countries with lower per-capita income, stable legal processes and exports concentrated in primary goods. However, it is not possible to examine the influence of elections on compliance sensibly with duration analysis. ${ }^{2}$ Therefore, a different approach is used here.

The article proceeds as follows. Section II surveys empirical evidence on compliance with IMF conditionality. However, apart from possible influences of elections on non-compliance, no attempt is made to identify reasons for past breakdowns. ${ }^{3}$ In section III, I present my own panel analysis. Section IV sums up and proposes reforms. 


\section{COMPLIANCE WITH IMF CONDITIONALITY}

Evidence on compliance with IMF conditionality was presented by Beveridge and Kelly [1980]. They showed that out of 105 countries with upper-credit-tranche programmes implemented between 1969-78 only 60 per cent achieved the target for the overall fiscal deficit and 54 per cent complied with the credit ceiling. However, they did not analyse the reasons for this low compliance. There is, of course, case study evidence illuminating possible reasons. One example is the programme negotiated with Peru in 1977. This programme failed chiefly because targets for the overall budget deficit were not met. Prior to legislative elections in June 1978, monetary expansion surged to more than 60 per cent and foreign direct investment declined drastically. In the second quarter of 1978 the country was almost bankrupt. In September, three months after the election, a new IMF arrangement was concluded. The programme included conditions on increases in bread and fuel prices, an elimination of most subsidies, an increase in interest rates and restricted government spending [Cline, 1983]. The targets for the 1978 programme were substantially met, the external deficit was down to ten per cent of the exports. Obviously, it would have been difficult to enforce such conditions prior to elections.

Another breakdown in which elections might have played a role is that of Tanzania in 1975. The IMF refused to disburse the second tranche of a Stand-by Arrangement initiated in August 1975 because the Tanzanian government did not comply with the accepted conditions [Cline, 1983]. Specifically, officials were not able to reduce government spending and monetary growth - maybe because of the oil price shock and a worldwide recession. Moreover, legislative and presidential elections held in October could have caused non-compliance. In Kenya the government concluded a two-year upper-tranche Stand-By Arrangement in August 1979, anticipating financing needs prior to presidential elections in November. Most conditions have been implemented as negotiated. However, the ceilings on bank credit to the government during July-December were greatly exceeded [Killick, 1983: 401]. Although failure to achieve the targets was partly due to over-ambitious ceilings, the IMF did not disburse the agreed money. A similar case is Egypt, where disbursements have been interrupted around legislative elections in June 1979.

Another study on interruptions of IMF programmes is Haggard [1985], who reports extremely low rates of compliance with conditions under the Extended Fund Facility (EFF) between 1974 and 1984. Of the 30 cases studied, sixteen were cancelled and eight more were not implemented in their original form. Zulu and Nsouli [1985] found similar results in a study of African adjustment programmes between 1980 and 1981. Only half of the countries achieved the negotiated credit ceilings. Moreover, compliance 
with fiscal targets has been poor. According to Edwards [1989], conditions on the government's deficit have been achieved in only 30 per cent of 34 programmes approved in 1983. In 1984 compliance was reduced further: the ceiling was observed in only 19 per cent of the programmes. One year later, 57 per cent of these countries failed to comply. As for changes in domestic credit, compliance was highest in 1983 (54.8 per cent). It reduced to 46.4 per cent in 1984 and 40.9 per cent in 1985. On average, compliance was higher for changes in net domestic credit to the government with 72 per cent in 1983 and about 52 per cent in 1984 and 1985. An illuminating example for repeated non-compliance with IMF conditions during this period is Jamaica. ${ }^{4}$

Prior to elections in December 1976, a tentative IMF arrangement including conditions on a wage freeze, a curbing of the deficit and a 20-40 per cent devaluation was negotiated. During the election year, however, government spending rose 20 per cent, despite declining revenues. Nevertheless, in August 1977 a rather lenient arrangement has been concluded, probably due to diplomatic support from Britain and Canada. The arrangement broke down in December, partly because of wage increases for the police and the military. The following $1978 \mathrm{EFF}$ arrangement was cancelled in June 1979. However, a new arrangement including revised targets was concluded in the same month. Early in 1980, as Manley was forced to call an election, disbursements were again interrupted. Manley rejected the conditions required for re-activating negotiations and advocated a 'non-IMF' path [Polanyi-Levitt, 1983: 252]. Officially, the arrangement was not cancelled until April 1981, when a new programme was immediately concluded with the incoming government. In 1983 - when elections were held in December - the Fund granted a waiver in June so the agreed amount could be drawn. In September the programme was cancelled for non-compliance.

In Honduras, disbursements were interrupted for non-compliance in September 1981 [Haggard, 1985: 507]. In December, one month after legislative elections, agreement over a revised programme was achieved. At expiration in June 1982, almost half of the agreed amount had not been disbursed. Non-compliance in the pre-electoral period lead to programme cancellation in Sierra Leone in April 1982 and Zaire in June of the same year. The breakdown of the Zaire programme was chiefly due to budgetary problems. Expenditures in 1981 increased by 58.6 per cent over the previous year. There were large subsidies to the state oil-importing company and about 15,000 non-existing teachers on the government's pay roll [Haggard, 1985: 514].

In India, the government itself announced its intention not to draw further on its credit line prior to parliamentary elections in 1984. Another 
breakdown where elections might have been important is that of Mexico, where it came to large deviations from targeted public sector borrowing prior to the July 1985 election. In 1984 and 1985 the target was 5.5 and 3.5 per cent of GDP, respectively. The actual borrowing amounted to 8.7 per cent in 1984 and 9.9 per cent in 1985. Nevertheless, the IMF disbursed almost US\$300 million in June 1985. In Turkey, five months prior to the November 1983 election, a new IMF arrangement was concluded. Compliance - which was quite high during the previous period of military rule - was drastically reduced. Public investment expenditure as well as extra-budgetary funds were expanded. Those funds were used to buy electoral support for the governing party, for example, with mass housing programmes [Mosley et al., 1991: 147]. Ups and downs in Costa Rica's economic and social progress has partly been associated with electoral cycles as well [World Bank, 2000: 1]. Fiscal discipline usually weakens as presidential elections approach every four years, which results in noncompliance with IMF programme conditions. This has been the case, for example, prior to the February 1982 elections. As a consequence, the IMF interrupted the programme in November 1981 [Haggard, 1985: 507].

Negotiations over a new Stand-By Arrangement with the Philippine government were complicated by national assembly elections in May 1984. On the eve of this election, the Marcos administration ignored the economic situation [Killick, 1995: 115]. Nevertheless, the IMF did not retain money due in January. In Argentina, though compliance during the first half of 1983 was quite high, prior to presidential and legislative elections in October inflation surged to over 400 per cent and external payment arrears were accumulated. The public sector deficit exceeded the programmed amount and charges for public services were not increased as negotiated. Moreover, wages in the public sector have been raised above the agreed amount which resulted in expenditure overruns [Stiles, 1991]. Prior to legislative elections in November 1985, non-compliance was again evident. Government expenditures, especially transfers and subsidies, increased drastically. Nevertheless, the IMF disbursed credit tranches in January, August and September. In the campaign prior to the September 1987 legislative elections, the IMF austerity programme was an important topic. In spite of severe non-compliance the Fund disbursed more than US\$1 billion in July. Immediately before the election, the incumbent announced to refuse further conditions which are not nationally owned [Tussie and Botzman, 1992: 162].

Another arrangement that went off track prior to elections is Egypt's mid-1987 Stand-By programme. In the run-up to presidential elections in October, President Mubarak failed to adopt promised reforms. After disbursing the first tranche in May 1987, the IMF therefore suspended the 
arrangement. The Ukrainian election of March 1998 provides a more recent example. In the long-planned parliamentary election, Prime Minister Pustovoitenko tried to obtain as much money and administrative support as possible, while paying little attention to economics. In 1998, the budget deficit was more than twice as budgeted during the first quarter because the government used disbursements to appeal to various constituencies. As a consequence, most IMF targets had been missed. While Ukraine did not receive international financing from any other source [Aslund and de Ménil, 2000: 13], the IMF released tranches in December 1997 and February 1998.

Tony Killick [1995] used a proxy to show that from 305 IMF programmes between 1979 and 1993 only 47 per cent have been completed without interruptions. He showed that the completion rate is declining over time and that Stand-by Arrangements - compared to Extended Arrangements - are more likely to be completed. In addition, Killick gives evidence that highly indebted countries as well as countries with small amounts of IMF credit are less likely to complete a programme and that fiscal conditions are especially unlikely to be met. He also stresses that new programmes are concluded for political reasons even if non-compliance with the conditionality of previous ones is evident. Apart from the Jamaican case mentioned above, this was the case in Sudan where the IMF supported President Nimeiri despite of repeated slippage and a lack of government commitment to reform [Killick, 1995: 104]. In December 1981, directly after legislator elections, sugar subsidies were abruptly removed instead of letting them phase out, as agreed with the Fund. Moreover, petrol prices have been increased by almost 40 per cent [Stiles, 1991: 92]. The EFF programme was therefore cancelled in February 1982. However, a Stand-By Arrangement was concluded in the same month. Another example is the 1996 EFF credit for Russia three months prior to presidential elections where the US and German governments induced the IMF to support President Yeltsin [Goricki, 1999: 223]. This was despite the low compliance with conditions under the previous Stand-By Arrangement where Yeltsin, in the eve of parliamentary and presidential elections promised huge expenditure increases. Moreover, revenues were far behind expectations.

More recently, Mecagni [1999] evaluates 36 countries with an IMF programme under the Structural Adjustment Facility (SAF) or the Enhanced Structural Adjustment Facility (ESAF) approved between 1986 and the end of 1994. His findings show that 28 of the evaluated countries interrupted their programmes 51 times in total. 17 countries had more than one interruption. Only ten programmes were in effect for three or four years without any major interruption and policy slippage. 38 programmes made it at least one year, in the second year, 22 programmes remained in effect. 33 interruptions were caused by slippage on conditionality, only eight 
programmes broke down due to disagreements about future actions. In some cases, governments needed more time to get political support in their countries in favour of an IMF programme. In 1988-89, only 40 per cent of 17 countries with an SAF programme complied with the postulated credit ceiling. The same is true for the overall fiscal deficit. In ten of the reviewed interruption episodes there were political upheavals. Governments were therefore not able to make credible commitments.

In 12 programme interruptions elections played a role. There was, for example, a delay of 12 months in completing the review for the 1988 ESAF programme with Bolivia. Presidential elections were held in June 1993, the interruption started in April. However, the money was completely disbursed prior to the election. There were large deviations from fiscal targets, as well as from benchmarks on credit and international reserves. Moreover, reforms in the financial sector were delayed. In Burkina Faso, an SAF programme was cancelled between presidential elections in December 1991 and parliamentary elections in May 1992. Prior to the December election, tax collection efforts declined and there were insufficient attempts to compensate for the income reductions with expenditure cuts. Since administrative capacity was absorbed by the political agenda, the government finally requested a deferral of the reform programme [Diabré, 1999].

In September 1993, a scheduled ESAF review was not completed prior to the November elections in Equatorial Guinea. The programme went off track in several areas, fiscal and monetary expansion was excessive and structural reforms were delayed. In Ghana, the run-up to parliamentary and presidential elections in 1992 resulted in a breakdown of macroeconomic stabilisation [Tsikata, 2001: 7]. The same is true for Honduras, where the IMF agreement was in suspension due to missed fiscal targets prior to legislative and executive elections in November 1997 [Walker et al., 1997: 24]. Under Macedonia's ESAF, which was scheduled to expire in April 2000, no money was disbursed after June 1998. Prior to parliamentary elections in October, budget deficits rose - partly reflecting spending for electoral reasons. While fiscal policy in Guyana has generally been conservative, the public deficit surged upwards to nearly ten per cent in 1997 due to unexpected economic problems and generous infrastructure spending in advance of the country-wide elections in December [Office of US Trade Representative, 1999: 41]. The IMF therefore interrupted the programme and released no tranche between April and December. Similar problems occured in Guinea, Kenya, Mauritania, Nepal, Senegal, Sri Lanka and Togo [Mecagni, 1999: 223].

Mercer-Blackman and Unigovskaya [2000] give evidence on compliance in countries in transition to market economies. Of 33 countries analysed, only 17 implemented more than 50 per cent of the structural 
benchmarks included under their programme between 1993 and 1997. In some of the programmes that went off track, elections might have been important. For example, the 1993 programme with Hungary failed immediately after the arrangement was concluded and the first tranche had been paid out. This was in September, while parliamentary elections took place in May 1994. The same happened in Belarus in the run-up to parliamentary elections in December 1996. Again, only one tranche had been disbursed. In Bulgaria, an arrangement was concluded in July 1996, with the immediate release of the first tranche. Prior to presidential elections in October, macroeconomic mismanagement and poor financial discipline prevailed. This resulted in a severe banking and foreign exchange crisis in 1996-97 [IMF, 2001: 76]. Nevertheless, no more money was disbursed under this arrangement.

In spite of non-compliance a credit tranche was disbursed as scheduled to the Romanian government in December 1995. While no money was paid out in the following year, where parliamentary elections took place in November, the arrangement was finally extended and the whole amount of money could be drawn down. In Kazakhstan a programme was concluded in January 1994. The first tranche was immediately disbursed. In March, parliamentary elections were held which led to an interruption of the programme. The next tranche was disbursed in December.

In another recent study, the IMF [2001] reports compliance with structural benchmarks in 57 per cent of all programmes between 1987 and 1999. Compliance with performance criteria was almost ten per cent higher, while prior actions have been implemented in 80 per cent of the programmes analysed. The worst implementation rates were found for conditions relating to privatisation ( 45 per cent), the social security system (56 per cent) and public enterprise reforms (57 per cent). However, reasons for non-compliance have been evaluated only for a small subset of countries. In these countries, political and social opposition were major reasons for observed non-implementation.

To sum up the evidence, several studies did find influences of elections on compliance with loan conditions and programme interruptions. In some cases the IMF cancelled the arrangement, in others, tranches were disbursed as scheduled. But are these studies merely anecdotal or is it possible to find a systematic correlation between compliance and elections in creditor countries? This question will be addressed in the following paragraph.

\section{SOME NEW EVIDENCE: AN EMPIRICAL INVESTIGATION}

The regression used to assess the effect of elections on programme interruptions is a pooled time-series cross-section analysis (panel data). The 
annual data cover the years 1975-98 and extend to 104 countries. Since some of the data are not available for all countries or years, the panel data are unbalanced and the number of observations depends on the choice of explanatory variables. No significant fixed time effects, neither for individual years, nor for different decades were found. All variables, their precise definitions and data sources are listed in the appendix.

Unfortunately, no direct data on compliance are available. It is therefore necessary to employ a proxy. As Killick [1995: 58] points out, credit agreed but left undrawn may be a useful indicator of performance under a programme. After concluding an arrangement, part of the credit associated with it will be paid out immediately. The rest is payable in tranches. Since IMF credits are highly subsidised, countries have incentives to draw all the money available immediately. This is especially true in election years. However, the money is conditional on observance of several performance criteria. Unless a waiver is granted, non-compliance results in programme interruptions. Therefore, if there are large unused credit lines, noncompliance and interruptions are likely to be the cause.

In Killick's study a programme was taken as uncompleted if at least 20 per cent of the initial credit line remained undrawn at programme expiration. The results were compared with case studies on 48 programmes, where an almost perfect matching was achieved. Thus, a similar indicator was used here. However, using the original indicator, compliance is likely to be overstated. If countries fail to implement agreed conditions at the beginning of a multi-year arrangement, money will be withheld. In many cases this money will be paid out later, after agreement about future conditions is reached. Though non-compliance might be severe during major parts of the programme period, finally the whole amount is disbursed, what would not be reflected by Killick's indicator. Therefore, the dependent variable used here is a dummy which takes the value of one if in a certain year at least 25 per cent of the amount which would be available for that year under equal phasing remained undrawn and zero otherwise.

As can be seen in Table 1, according to this dummy, interruptions of IMF programmes are quite frequent. ${ }^{5}$ Between 1969 and 1998 more than 60 per cent of the agreed money was not disbursed as scheduled. The fraction of undisbursed money was lowest under the Structural Adjustment Facility and greatest under the Extended Fund Facility.

There are three main groups of variables which might influence these interruptions. One group accounts for the initial pressure to adjust. In some cases countries may not draw on their credit lines because they enter an arrangement only on a precautionary basis, without intending to draw on these credits. In this case, undrawn credit lines are large, even though no interruption occurs. On the other hand, countries in severe crisis depend on 
the IMF money since private credit flows are unavailable. With this external pressure, countries are more likely to comply with programme conditions. If performance criteria are nevertheless missed, the IMF probably waives the conditions. Interruptions are therefore less likely. The second group accounts for changes in economic variables. If conditions improve, compliance might no longer be necessary, so programmes are interrupted. Since many IMF conditions depend on the macroeconomic environment, however, positive changes might themselves result in (unintended) compliance. Finally, political factors probably influence compliance with conditionality.

In the case of each of the three groups, there is not one but several variables which could be used to measure its impact on compliance. From data sources commonly used in cross-country time-series estimation, data for 34 variables belonging to the groups just defined could be obtained.

TABLE 1

PROXY FOR INTERRUPTIONS OF IMF PROGRAMMES, 1969-981

\begin{tabular}{|c|c|c|c|}
\hline & $\begin{array}{c}\text { Number of } \\
\text { Programme years }\end{array}$ & $\begin{array}{l}\text { Frequency of } \\
\text { 'Interruptions' }\end{array}$ & $\begin{array}{c}\text { 'Interruptions' } \\
\text { in per cent }\end{array}$ \\
\hline All Programmes & 956 & 574 & 60.04 \\
\hline $1969-78$ & 144 & 103 & 71.53 \\
\hline $1979-88$ & 319 & 202 & 63.32 \\
\hline 1989-98 & 493 & 269 & 54.56 \\
\hline SAF & 87 & 33 & 37.93 \\
\hline $1969-78$ & 0 & 0 & 0 \\
\hline $1979-88$ & 53 & 13 & 24.53 \\
\hline 1989-98 & 34 & 20 & 58.82 \\
\hline ESAF/PRGF & 231 & 92 & 39.83 \\
\hline $1969-78$ & 0 & 0 & 0 \\
\hline $1979-88$ & 6 & 1 & 16.67 \\
\hline 1989-98 & 225 & 91 & 40.44 \\
\hline Stand-by Arrangements & 525 & 351 & 66.86 \\
\hline $1969-78$ & 133 & 95 & 71.43 \\
\hline $1979-88$ & 222 & 144 & 64.86 \\
\hline 1989-98 & 170 & 112 & 65.88 \\
\hline Extended Fund Facility & 151 & 112 & 74.17 \\
\hline $1969-78$ & 11 & 8 & 72.73 \\
\hline $1979-88$ & 61 & 47 & 77.05 \\
\hline 1989-98 & 79 & 57 & 72.15 \\
\hline
\end{tabular}

Source: www.imf.org and International Financial Statistics.

1. A programme is classified as 'interrupted' if in a certain year at least 25 per cent of the money that was available under equal phasing remained undrawn. 
Since many of them are highly collinear, it was impossible to include all of them in a single estimation. The strategy was thus to form groups of variables, and select the variables with the most robust impact on programme interruptions by iteratively replacing these variables with each other inside each of the groups. Since the dependent variable is binary, a probit model was used for these estimations.

The first step was to factor analyse the independent variables to recover the dimensionality of the data. It turned out that there is only one important dimension. This dimension can be interpreted as macroeconomic conditions during programme initiation excluding monetary growth and the overall budget deficit. In the iterative replacement procedure, I started with two variables from this group, replacing them with other covariates from the same group and retaining those which had the highest number of statistically significant coefficients. All variables which did not have a coefficient significant at the ten per cent level in more than a third of the regressions run were dropped. The procedure led to the choice of the following variables for the base regression (all measured at the beginning of the programme period):

- government consumption (in per cent of GDP);

- short-term debt (in per cent of GDP); and

- GDP per capita.

The same procedure was employed to political variables and changes in macroeconomic variables. It turned out that non of them is robustly related to programme interruptions. ${ }^{6}$

As can be seen in column 1 of Table 2, programme interruptions are significantly more likely in countries with high government consumption and lower per capita GDP at the beginning of an IMF programme. Reduction of government expenses is a condition frequently included under IMF programmes. This condition will probably lead to stronger opposition, the larger the governments' share in GDP. Large government consumption usually comes along with larger and often more powerful bureaucracies who prevent conditions from being implemented. Therefore, interruptions occur more frequently if the IMF does not waive the initial conditions. Such waivers are probably easier to achieve the more influence a country has in the Executive Board. Since voting rights rise with GDP, the IMF will probably be more lenient with richer countries which results in lower interruption probabilities. Moreover, those countries have more influence on programme design than do poorer countries. ${ }^{7}$

Interruptions are significantly more frequent with higher short-term debt at the beginning of the programme. Short-term debt as a per cent of GDP 
controls for the severity of the crisis. It seems that the IMF does not accurately take the initial situation into account when designing its conditionality.

The results for all three variables will hold, regardless of the choice of control variables. The regression is able to predict the dependent variable correctly in 76 per cent of the cases.

To control for the influences of elections, two indices were used. They measure the share of a certain year, which is within twelve months prior to

TABLE 2

PROXY FOR INTERRUPTIONS OF IMF PROGRAMMES

(PANEL DATA, 104 COUNTRIES, 1975-98, RANDOM EFFECTS PROBIT)

\begin{tabular}{|c|c|c|c|c|c|c|}
\hline explanatory variables & (1) & (2) & (3) & (4) & (5) & (6) \\
\hline pre-election index & & $\begin{array}{l}0.03 \\
\left(2.23^{*}\right)\end{array}$ & $\begin{array}{c}0.09 \\
(1.57)\end{array}$ & $\begin{array}{l}0.28 \\
\left(2.06^{*}\right)\end{array}$ & $\begin{array}{l}0.38 \\
\left(2.36^{*}\right)\end{array}$ & $\begin{array}{l}0.38 \\
\left(1.73^{* *}\right)\end{array}$ \\
\hline $\begin{array}{l}\text { pre-election index } * \text { index } \\
\text { for democracy }\end{array}$ & & & & $\begin{array}{l}-0.06 \\
(-1.83 * *)\end{array}$ & $\begin{array}{l}-0.05 \\
(-1.30)\end{array}$ & $\begin{array}{l}-0.082 \\
(-1.94 * *)\end{array}$ \\
\hline post-election index & & $\begin{array}{c}0.05 \\
(0.34)\end{array}$ & $\begin{array}{c}0.04 \\
(0.25)\end{array}$ & $\begin{array}{c}0.16 \\
(0.86)\end{array}$ & $\begin{array}{l}-0.01 \\
(-0.02)\end{array}$ & $\begin{array}{l}-0.11 \\
(-0.38)\end{array}$ \\
\hline $\begin{array}{l}\text { post-election index } * \text { index } \\
\text { for democracy }\end{array}$ & & & & $\begin{array}{l}-0.05 \\
(-1.40)\end{array}$ & $\begin{array}{l}-0.05 \\
(-1.17)\end{array}$ & $\begin{array}{l}-0.02 \\
(-0.31)\end{array}$ \\
\hline $\begin{array}{l}\text { government consumption, } \\
\text { initial value (percent } \\
\text { of GDP) }\end{array}$ & $\begin{array}{c}0.07 \\
\left(8.53^{\circ}\right)\end{array}$ & $\begin{array}{c}0.06 \\
\left(7.02^{\mathrm{o}}\right)\end{array}$ & $\begin{array}{c}0.05 \\
\left(6.83^{\circ}\right)\end{array}$ & $\begin{array}{c}0.05 \\
\left(6.77^{\circ}\right)\end{array}$ & $\begin{array}{c}0.08 \\
\left(5.62^{\mathrm{o}}\right)\end{array}$ & $\begin{array}{c}0.05 \\
\left(4.23^{\mathrm{o}}\right)\end{array}$ \\
\hline gdp per capita, initial value & $\begin{array}{l}-0.23 \\
\left(-3.51^{\mathrm{o}}\right)\end{array}$ & $\begin{array}{l}-0.25 \\
\left(-3.32^{\mathrm{o}}\right)\end{array}$ & $\begin{array}{l}-0.22 \\
\left(-3.44^{\mathrm{o}}\right)\end{array}$ & $\begin{array}{l}-0.22 \\
\left(-3.35^{\circ}\right)\end{array}$ & $\begin{array}{l}-0.31 \\
\left(3.00^{\mathrm{o}}\right)\end{array}$ & $\begin{array}{l}-0.25 \\
\left(-2.88^{\mathrm{o}}\right)\end{array}$ \\
\hline $\begin{array}{l}\text { short-term debt, initial } \\
\text { value (percent of GDP) }\end{array}$ & $\begin{array}{l}0.02 \\
\left(2.93^{\mathrm{o}}\right)\end{array}$ & $\begin{array}{l}0.02 \\
\left(3.10^{\circ}\right)\end{array}$ & $\begin{array}{l}0.02 \\
\left(3.14^{\mathrm{o}}\right)\end{array}$ & $\begin{array}{l}0.02 \\
\left(3.18^{\mathrm{o}}\right)\end{array}$ & $\begin{array}{l}0.02 \\
(2.42 *)\end{array}$ & $\begin{array}{l}0.03 \\
\left(3.51^{\circ}\right)\end{array}$ \\
\hline index for democracy & & & $\begin{array}{l}0.13 \\
\left(1.76^{* *}\right)\end{array}$ & $\begin{array}{c}0.04 \\
\left(2.46^{*}\right)\end{array}$ & $\begin{array}{l}0.04 \\
(2.04 *)\end{array}$ & $\begin{array}{c}0.04 \\
(1.51)\end{array}$ \\
\hline $\begin{array}{l}\text { overall budget deficit, initial } \\
\text { value }\end{array}$ & & & & & $\begin{array}{l}-0.03 \\
(-2.42 *)\end{array}$ & $\begin{array}{l}-0.01 \\
(-1.00)\end{array}$ \\
\hline $\begin{array}{l}\text { monetary growth rate, initial } \\
\text { value }\end{array}$ & & & & & $\begin{array}{c}0.01 \\
(1.58)\end{array}$ & \\
\hline past interruptions & & & & & & $\begin{array}{c}1.57 \\
\left(10.78^{\circ}\right)\end{array}$ \\
\hline constant & $\begin{array}{c}-0.44 \\
\left(-3.69^{\circ}\right)\end{array}$ & $\begin{array}{l}-0.34 \\
\left(-2.53^{*}\right)\end{array}$ & $\begin{array}{l}-0.29 \\
(-2.38 *)\end{array}$ & $\begin{array}{c}-0.36 \\
\left(-2.82^{\mathrm{o}}\right)\end{array}$ & $\begin{array}{c}-0.46 \\
(-2.07 *)\end{array}$ & $\begin{array}{l}-1.10 \\
\left(-4.89^{\circ}\right)\end{array}$ \\
\hline $\begin{array}{l}\text { percent of correct } \\
\text { predictions }\end{array}$ & 76 & 76 & 77 & 78 & 78 & 81 \\
\hline log likelihood & -542.74 & -470.80 & -438.27 & -424.41 & -269.57 & -199.98 \\
\hline number of countries & 104 & 93 & 88 & 88 & 67 & 65 \\
\hline number of observations & 940 & 817 & 761 & 761 & 493 & 484 \\
\hline
\end{tabular}

Notes: A programme is classified as 'interrupted' if in a certain year at least 25 per cent of the money that was available under equal phasing remained undrawn.

$\mathrm{t}$-statistics in parentheses:

o: significant at the one per cent level

*: significant at the five per cent level

**: significant at the ten per cent level 
or after a national election, respectively. With these indices it is possible to distinguish that part of a year, which is prior to elections from the postelection time. For example, if an election would be in February, the preelection index would take the value of $1 / 12$ in that year and 11/12 in the previous year. The post-election index would take the values of 10/12 in the election year and 2/12 in the following one.

As can be seen in column 2, interruptions of IMF programmes are significantly more frequent prior to elections. ${ }^{8}$ Since the regression controls for initial imbalances, and changes in economic variables turned out insignificant, this is probably due to increased non-compliance during election times. However, this result is not completely robust to the choice of control variables.

In the year after the election there seems to be, on average, no significant change in programme interruptions.

Column 3 includes an index measuring the degree of democracy in the recipient country. The effect of democracy on adjustment policies has frequently been discussed in the literature [e.g., Diamond and Plotter, 1995; Mosley et al., 1991]. It is often asserted that since authoritarian governments face no democratic opposition they are more likely to implement reforms. On the other hand, to legitimise the authoritarian leader, elections in an undemocratic context often have a high degree of competition while some democratic elections have not. The influence of democracy on interruptions is therefore not clear a priori. The variable used to account for this influence is an index ranging from zero to ten. It is constructed to measure the general openness of political institutions with ten indicating the highest level. As can be seen, interruptions are more frequent in the more democratic countries - probably because in democracies governments depend on popular support of their policies. ${ }^{9}$

With the inclusion of democracy, the pre-election index looses its significance. It seems that this index captured partly the influence of democratic competition in the borrowing countries. To examine this in more detail, column 4 distinguishes between genuinely democratic elections and elections under more authoritarian regimes. Therefore, the election indices are interacted with the democracy index. While the index for democracy now is significant at the five per cent level, the joint influence of democracy and elections is negative and significant at the ten per cent level. With the inclusion of this variable, the pre-election index is again significant.

Compared to the previous results, the quantitative effect of the index is more than three times larger. Calculated at the mean of the independent variables (and assuming random effects equal to zero), the probability of interruption increases by 0.75 percentage points with each additional month that lies within 12 months prior to an election (not reported in the Table). 
The positive overall influence of elections on interruption probabilities decreases in more democratic countries and becomes negative with an index of democracy greater than $4.5 .{ }^{10}$ Since it is highly unlikely that compliance with conditionality prior to elections is higher, the IMF seems to be more lenient with democratic governments - probably in order to support the incumbent. After the election interruption probabilities again do not significantly change with respect to the average.

In column 5, the overall budget deficit and monetary growth rate of the recipient country at the beginning of the programme period are included. Those variables are of outstanding importance in IMF programmes. Usually, they are made performance criteria for tranche disbursements. Moreover, prior to elections budget deficits and monetary growth rates typically surge. The analysis therefore has to allow for this correlation. However, only the coefficient of the overall budget deficit is significant in the regression. ${ }^{11}$ Since high deficits can indicate an economic crisis, the negative sign is surprising. Maybe the IMF takes those deficits into account when designing its programme conditions and is therefore less demanding. The coefficient of the deficit is, however, not robust to the inclusion of other variables. Changes in the rate of monetary growth and the overall budget deficit relative to the previous year were tried, but received completely insignificant coefficients (not reported). It seems, however, that interruptions due to improvements in the macroeconomic environment are irrelevant. With the inclusion of budget deficits and monetary growth rates, the index for more democratic elections no longer is significant at conventional levels. The coefficient of the pre-election index stays significant at the five-per-cent level.

Finally, column 6 includes a dummy for past programme interruptions. ${ }^{12}$ This dummy is highly significant, with a positive coefficient. The result implies that interruptions are more likely if past non-compliance was high. ${ }^{13}$ With the inclusion of this variable, the index for democracy and the overall budget deficit are no longer significantly correlated with programme interruptions. The pre-election index as well as its interaction with the democracy index are significant at the ten per cent level. The final regression is able to predict programme interruptions correctly in 81 per cent of the cases. Owing to data constraints, the number of observations almost halved compared to the first regression.

To summarise, the results are compatible with the above stated hypotheses: prior to national elections, non-compliance with loan conditions seems to be generally more likely. As a result, the IMF interrupts the arrangements. Interruptions prior to elections become, however, less likely with rising democracy. The probability of cancellation is not significantly influenced by post-election processes. Except for democracy, 
no other political variables seem to have a systematic influence on interruptions of disbursements.

\section{CONCLUSION}

Compliance with conditionality under IMF programmes is traditionally quite low. As a consequence, the IMF often cancels the arrangement. However, in most cases some of the money has been disbursed. Moreover, the Fund immediately concludes new arrangements after previous failures. This response seems to be inappropriate. Countries that fail to comply with (important) programme conditions should immediately be excluded from new money. That would mean that the current programme would have to be cancelled and that no new arrangements should be concluded with that government. Another way to adjust the disproportion between money paid out and conditionality implemented would be to pay out tranches only after agreed conditions have been met. This procedure has recently been introduced under the World Bank's Higher Impact Adjustment Lending and would be a good instrument at least for the longer term assistance from the IMF. A similar proposal has been made by Vaubel [1991] and the International Financial Institutions Advisory Commission [1999] who proposed to establish IMF conditionality on an ex-ante basis. If tranches were released only after compliance with certain codes of good practise, less money would be paid to failing countries. This principle has been established for the IMF's contingent credit line which, however, has not been used so far.

To the extent that conditionality is ex post, the interest rate on the loan could be made contingent on compliance. Low compliance would lead to an interest penalty.

A better selection of countries may also reduce non-compliance. Past compliance, low government consumption, a low share of short-term debt in GDP and high per capita GDP at the beginning of the programme period were found to be reliable indicators of future compliance. However, it is not evident which political factors - other than elections and democracy influence compliance systematically.

With respect to elections, it has been shown that the share of money disbursed under IMF programmes is significantly smaller prior to elections and that more democratic countries receive more money at this time. Evidence from case studies suggests that the IMF frequently concludes arrangements immediately prior to elections and pays out some of the money in spite of non-compliance. To avoid interference with domestic political processes, the Fund should change this practice. Former IMF Managing Director Michel Camdessus [1996] has objected that the postponement of a programme at election times would be a political act in 
its own right. However, the real political act is increased tolerance of noncompliance and increased lending at election time.

final revision accepted January 2003

\section{NOTES}

1. Dreher [2002] provides a detailed description of IMF conditionality and reasons for its evolution. Not all of those conditions are, however, imposed by outside actors. In some cases, governments might include their own policies in IMF programmes to restrict internal opposition [Remmer, 1986: 21].

2. This is because compliance usually can not be observed over an extended period. Moreover, with only yearly data available, the number of observations would be quite limited. For example, Joyce [2001] reports a maximum of 45 quarters under IMF programmes. According to the indicator used here, the longest interruption and no-interruption spells are six and nine years, respectively.

3. Excellent surveys on this are Kahler [1992] and Haggard [1985].

4. The relationship between Jamaica and the IMF is summarised in Haggard [1992: 520-25]. A more comprehensive study is Polanyi-Levitt [1983].

5. Similar results were achieved by Killick [1995: 62]. This is in contrast to the findings of Mussa and Savastano [1999: 16] who report a higher fraction of disbursements. However, since they present the share of IMF loans actually disbursed at programme expiration this is no adequate indicator for programme interruptions.

6. Apart from variables included in later columns, the following political variables have been tried: currency crises [Hutchinson, 2003], government fractionalisation of legislature, strength of the president, an index of political cohesion, total legislature fractionalisation, political leaning of the chief executive's party, autonomous regions, nationalist executive party, military chief executives [all Beck et al.] and a dummy for IMF quota reviews [http//www.imf.org]. With respect to economic variables, changes in levels have been tested for gross international reserves, GDP per capita, overall budget deficit, inflation, foreign direct investment, short-term debt, total debt service, long-term debt, current account balance and GDP growth [all IBRD, 2000]. Since no robustly significant coefficients were found, the results are not reported.

7. This is endorsed by case study evidence [e.g., Cornelius, 1988: 75].

8. If time dummies for election years, pre-election years and post-election years are used instead, only the election year dummy is significant, with a negative sign.

9. If a binary indicator constructed by Alvarez et al. [1996] is used instead its coefficient is completely insignificant.

10. The (in-sample) mean of the democracy index is 3.09 , its median is 1 .

11. This is contrary to Ergin [1999] who found a significant effect of monetary growth on programme participation.

12. Since it is completely irrelevant, monetary expansion is excluded from the regression.

13. I also included dummies for different geographical regions but did not find any significant influence. To check whether the observed differences in the share of undisbursed money between arrangements (Table 1) are significant I also included dummies for different IMF facilities. However, due to the insignificance of all coefficients the results are not reported in the Table.

\section{REFERENCES}

Alvarez, Mike et al., 1996, 'Classifying Political Regimes', Studies in Comparative International Development, Vol.31, No.2, pp.2-36.

Aslund, Anders and Georges de Ménil, 2000, Economic Reform in Ukraine: The Unfinished Agenda, New York: M.E. Sharpe.

Beck, Thorsten, Clarke, G., Groff, A. and P. Keefer, 1999, New Tools and New Tests in 
Comparative Political Economy: The Database of Political Institutions, Development Research Group, Washington, DC: World Bank.

Beveridge, W.A. and M.R. Kelly, 1980, Fiscal Content of Financial Programmes Supported by Stand-By Arrangements in the Upper Credit Tranches, 1969-78, IMF Staff Papers, Vol.27, pp.205-49.

Camdessus, Michael, 1996, Camdessus on IMF Support for Russian Reforms, IMF Survey, Vol.25, No.8, pp.129-30.

Cline, William, 1983, 'Economic Stabilisation in Developing Countries: Theory and Stylised Facts', in John Williamson (ed.), IMF Conditionality, Washington, DC: Institute for International Economics, pp.175-208.

Cornelius, Peter, 1988, Das Prinzip der Konditionalität bei Krediten des Internationalen Währungsfonds, München: Verlag V. Florentz GmbH.

Diabré, Zéphirin, 1999, 'The Political Economy of Adjustment in Burkina Faso', CAER II Discussion Paper 28, Harvard Institute for International Development.

Diamond, Larry and Marc F. Plattner, 1995, Economic Reform and Democracy, Baltimore, MD: Johns Hopkins University Press.

Dollar, David and Jakob Svensson, 1998, 'What Explains the Success or Failure of Structural Adjustment Programmes?', Policy Research Paper 1938, Washington, DC: World Bank.

Dreher, Axel, 2002, 'The Development and Implementation of IMF and World Bank Conditionality, HWWA Discussion Paper 165, Hamburg: Hamburgisches Welt-WirtschaftsArchiv.

Dreher, Axel and Roland Vaubel, 2004, 'Do IMF and IBRD Cause Moral Hazard and Political Business Cycles? Evidence from Panel Data', Open Economic Review, Vol.15, No.1, forthcoming Jan. 2004.

Edwards, Sebastian, 1989, 'The International Monetary Fund and the Developing Countries: A Critical Evaluation', Carnegie-Rochester Conference Series on Public Policy: IMF Policy Advice, Market Volatility, Commodity Price Rules and other Essays, Amsterdam: NorthHolland, pp.7-68.

Ergin, Evren, 1999, 'Determinants and Consequences of International Monetary Fund Programmes', Ph.D. dissertation, Stanford University.

Goricki, Clarissa, 1999, Marktwirtschaftliche Reformsteuerung - Die Rolle von IWF und Weltbank in Mittelosteuropa nach 1990, Singapur: Verlag Fakultas.

Haggard, Stephan, 1985, 'The Politics of Adjustment: Lessons from the IMF's Extended Fund Facility', International Organization, Vol.39, No.3, pp.505-34.

Hutchinson, Michael M., 2003, 'A Cure Worse than the Disease? Currency Crises and the Output Costs of IMF-Supported Stabilisation Programmes', in Michael P. Dooley and Jeffrey A. Frankel (eds.), Managing Currency Crises in Emerging Markets, NBER Conference Report, Ch.10.

International Bank for Reconstruction and Development, 2000, World Development Indicators CD-ROM.

International Financial Institutions Advisory Commission, 1999, Report, http://phantomx.gsia.cmu.edu/IFIAC/USMRPTDV.html, 1.9.2000.

International Monetary Fund, 1997, 'The ESAF at Ten Years, Economic Adjustment and Reform in Low-Income Countries', IMF Occasional Paper 156, Washington, DC.

International Monetary Fund (2001), Structural Conditionality in Fund-Supported Programmes, February 16, http://www.imf.org.

International Monetary Fund, 2000, International Financial Statistics CD-ROM, Washington, DC.

Johnson, J.H. and S.S. Wasty, 1993, Borrower Ownership of Adjustment Programmes and the Political Economy of Reform, World Bank Discussion Paper 199, World Bank, Washington, DC.

Joyce, Joseph P., 2001, 'Time Present and Time Past: A Duration Analysis of IMF Programme Spells', Federal Reserve Bank of Boston Working Paper No.01-2, March.

Kahler, Miles, 1992, 'External Influence, Conditionality, and the Politics of Adjustment', in Stephan Haggard and Robert R. Kaufman (eds.), The Politics of Adjustment, Princeton, NJ: Princeton University Press.

Killick, Tony, 1983, 'Kenya, the IMF, and the Unsuccessful Quest for Stabilization', in John Williamson (ed.), IMF Conditionality, Washington, DC: Institute for International Economics, pp.381-414. 
Killick, Tony, 1995, IMF Programmes in Developing Countries - Design and Impact, London: Routledge.

Marshall, Monty G., and Keith Jaggers, 2000, 'Polity IV Dataset Project: Political Regime Characteristics and Transitions, 1800-1999', http://www.bsos.umd.edu/cidcm/ polity.

Mecagni, Mauro, 1999, 'The Causes of Programme Interruptions', in H. Bredenkamp and S. Schadler (eds.), Economic Adjustment in Low-Income Countries, Washington, DC: International Monetary Fund, pp.215-76.

Mercer-Blackman, Valerie and Anna Unigovskaya, 2000, 'Compliance with IMF Programme Indicators and Growth in Transition Economies', IMF Working Paper 47, Washington, DC.

Mosley, Paul, Harrigan, Jane and John Toye, 1991, Aid and Power - The World Bank and Policybased Lending, Vol.1, New York: Routledge.

Mussa, Michael and Miguel Savastano, 1999, 'The IMF Approach to Economic Stabilisation', IMF Working Paper, Washington, DC.

Office of the United States Trade Representative, 1999, Third Report to the Congress on the Operation of the Caribbean Basin Economic Recovery Act October 1.

Polanyi-Levitt, Kari, 1983, 'Jamaica: Manley's Defeat - Whose Responsibility?, in J. Torrie (ed.), Banking on Poverty - The Global Impact of the IMF \& World Bank, Toronto, Canada, pp.241-60.

Remmer, Karen, 1986, 'The Politics of Economic Stabilization: IMF Standby Programmes in Latin America, 1954-1984', Comparative Politics, Vol.9, No.1, pp.1-24.

Schuknecht, Ludger, 1996, 'Political Business Cycles and Fiscal Policies in Developing Countries', Kyklos, Vol.49, No.2, pp.155-70.

Stevens, Mike and Shiro Gnanaselvam, 1995, 'The World Bank and Governance', IDS Bulletin, Vol.26, pp.97-105.

Stiles, Kendall W., 1991, Negotiating Debt, San Francisco, CA: Westview Press.

Tsikata, Yvonne M., 2001, 'Owning Economic Reforms: A Comparative Study of Ghana and Tanzania', WIDER Discussion Paper No.2001/53.

Tussie, Diana and Mirta Botzman, 1992, 'Sweet Entanglement: Argentina and the World Bank (1985-89)', in Ennio Rodríguez and Stephany Griffith-Jones (eds.), Cross-Conditionality, Banking Regulation and Third World Debt, London: Macmillan, pp.156-90.

Vaubel, Roland, 1991, 'The Political Economy of the International Monetary Fund: A Public Choice Approach', in Roland Vaubel and Thomas D. Willett (eds.), The Political Economy of International Organisations, Boulder, CO: Westview, pp.205-45.

Walker, Ian, Velásquez, Max, Ordoñez, Fidel and Florencia Rodríguez, 1997, 'Regulation, Organization and Incentives: The Political Economy of Potable Water Services in Honduras', Inter-American Development Bank Working Paper R-314, Nov.

World Bank, 2000, 'Costa Rica Country Assistance Evaluation', Memorandum to the Executive Directors and the President, Nov. 16.

Zulu, Justin B. and Saleh, M. Nsouli, 1985, Adjustment Programmes in Africa: The Recent Experience, IMF Occasional Papers 34, Washington, DC.

\section{APPENDIX}

\section{Definitions and Data Sources}

'IMF Programme Interruptions', http://www.imf.org and International Financial Statistics (2000): Dummy that takes the value of one, if at least 25 per cent of the money available under equal phasing of the amount initially agreed upon in an arrangement remains undrawn in a certain year.

'Election Period', Beck et al. [1999]: The pre-election index measures the share of a certain year which was within twelve months prior to a nation-wide executive election. The post-election index measures the share of a certain year which was within twelve months after a nation-wide executive election. 
'Government consumption in per cent of GDP', International Bank for Reconstruction and Development (2000): Includes all current spending for purchases of goods and services (including wages and salaries). It also includes most expenditures on national defense and security, but excludes government military expenditures that are part of government capital formation.

'GDP per capita based on purchasing power parity', International Bank for Reconstruction and Development [2000]: Gross domestic product converted to international dollars using purchasing power parity rates. An international dollar has the same purchasing power over GDP as the US dollar in the United States. GDP measures the total output of goods and services for final use occurring within the domestic territory of a given country, regardless of the allocation to domestic and foreign claims. Gross domestic product at purchaser prices is the sum of gross value added by all resident producers in the economy plus any taxes and minus any subsidies not included in the value of the products. It is calculated without making deductions for depreciation of fabricated assets or for depletion and degradation of natural resources. The residency of an institution is determined on the basis of economic interest in the territory for more than a year.

'Short-term debt (per cent of total external debt)', International Bank for Reconstruction and Development [2000]: Short-term debt includes all debt having an original maturity of one year or less and interest in arrears on long-term debt.

'Democracy Index', Marshall et al. [2000]: General openness of political institutions ( $0=$ low; $10=$ high). The 11-point scale is constructed additively. Its components refer to the transfer of executive power, the extent to which executives are chosen through competitive elections, opportunities for non-elites to attain executive office, the operational (de facto) independence of chief executive, development of institutional structures for political expression and the extent to which non-elites are able to access institutional structures for political expression.

'Overall Budget Deficit in per cent of GDP', International Bank for Reconstruction and Development (2000): Overall budget deficit is total expenditure and lending minus repayments less current and capital revenue and official grants received. Data are for central government only.

'Monetary Expansion', International Bank for Reconstruction and Development [2000]: Average annual growth rate in money and quasi money. The change in the money supply is measured as the difference in end-of-year totals relative to the level of M2 in the preceding year. 